EL DINAR: Jurnal Keuangan dan Perbankan Syariah

Volume 7 , No. 1, Tahun 2019

P ISSN: 2339-2797; E ISSN: 2622-0083

\title{
DETERMINAN TINGKAT SUKU BUNGA, INDEKS DOW JONES, NIKKEI 225, DAN STRAITS TIME TERHADAP ISSI
}

\author{
Febrian Wahyu Wibowo \\ UIN Sunan Kalijaga Yogyakarta \\ febrianwahyu94@gmail.com
}

\section{ABSTRACT}

Islamic financing is a kind of investment that has system and operational based on sharia principles. Islamic financing is supervised by the Sharia Supervisory Board (DPS). This is to safeguard that there are no commercial involved such as gambling, usury, and prohibitedproducts. The indexfluctuation in the capital market of a country is influenced by world capital market indices. The first Islamic index in world is the Dow Jones Islamic Market Index (DJIM). Based on the discussion about the influence of Interest Rate variables, Dow Jones Islamic Market, Nikkei 225 Index, and Straits Times Index on the Indonesian Sharia Stock Index variable for June 2012 until March 2017 the conclusions are as follows: Interest Rate has a negative effect on the Indonesian Sharia Stock Index, Dow Jones Islamic Market has a positive effect on the Indonesian Sharia Stock Index, the Nikkei 225 has a negative effect on the Indonesian Sharia Stock Index, the Straits Times negatively affects the Indonesian Sharia Stock Index.

Keywords: Sharia Shares, Interest Rate, DJIM, Nikkei 225.

\section{ABSTRAK}

Investasi syariah adalah jenis investasi yang sistem dan operasionalnya berdasarkan prinsip-prinsip syariah. Investasi syariah diawasi oleh Dewan Pengawas Syariah (DPS). Hal ini untuk memastikan tidak adanya bisnis yang terlibat dalam kegiatan seperti judi, riba, dan produk yang diharamkan. Pergerakan indeks di pasar modal suatu Negara juga dipengaruhi oleh indeks-indeks pasar modal dunia. Indeks syariah pertama di dunia adalah Dow Jones Islamic Market Index (DJIM). Berdasarkan pembahasan yang telah dikemukakan mengenai pengaruh variabel Tingkat Suku Bunga, Dow Jones Islamic Market, Indeks Nikkei 225, dan Indeks Straits Times terhadap variable Indeks Saham Syariah Indonesia untuk periode Juni 2012 sampai dengan Maret 2017 dapat diambil kesimpulan sebagai berikut : Tingkat Suku Bunga berpengaruh negative terhadap Indeks Saham Syariah Indonesia, Dow Jones Islamic Market berpengaruh positif terhadap Indeks Saham Syariah Indonesia, Nikkei 225 berpengaruh negatif terhadap Indeks Saham Syariah Indonesia, Straits Times berpengaruh negatif terhadap Indeks Saham Syariah Indonesia.

Kata kunci :Saham Syariah, suku bunga, DJIM, Nikkei 225 


\section{Febrian Wahyu Wibowo: Pengaruh Tingkat Suku Bunga PENDAHULUAN}

Investasi secara syariah merupakan investasi yang dioperasionalkan sesuai dengan syariah. Investasi tersebut harus melewati proses screening dan disetujui oleh Dewan Pengawas Syariah (DPS) untuk memastikan tidak adanya bisnis yang terlibat dalam kegiatan seperti judi, riba, dan produk yang diharamkan (seperti babi, tembakau, alkohol, dan senjata). Indeks syariah pertama di dunia adalah Dow Jones Islamic Market Index (DJIM).Indeks ini diciptakan untuk para investor yang ingin menempatkan investasinya sesuai dengan aturan syariah (Bodie, 2014).Berbagai pasar modal dan lembaga keuangan di seluruh dunia kemudian turut mendirikan indeks syariah (Shariah compliant index) sendiri, misalnya, FTSE Shariah Global Equity Index Series, dan Kuala Lumpur Stock Exchange Shari'ah Index (KLSESI).

Pasar modal syariah di Indonesia menunjukkan peningkatan pangsa pasar yang tercermin antara lain dari jumlah saham syariah, nilai kapitalisasi pasar dan jumlah reksadana syariah.Terdapat beberapa risiko yang tidak dapat dihindari oleh investor di pasar modal yaitu terkait dengan kondisi mekroekonomi. Kinerja pasar modal syariah yang tercermin pada Indeks Saham Syariah Indonesia juga tidak bisa menghindari dari risiko-risiko tersebut. Fenomena ketidakstabilan yang terdapat pada variabel makro akan menjadikan peningkatan pada investasi yang tidak menarik di mata investor, sehingga membuat para investor mengalihkan laba yang sudah diinvestasikannya dalam bentuk saham ke dalam bentuk investasi lainnya. Akibatnya, hal ini akan memicu menurunnya kinerja perusahaan yang kemudian berdampak terhadap harga pasar saham.Secara umum terdapat beberapa faktor mekroekonomi yang memperngaruhi pergerakan harga saham, antara lain tingkat suku bunga dan nilai tukar USD terhadap Rupiah.

Pergerakan indeks di pasar modal suatu Negara juga dipengaruhi oleh indeks-indeks pasar modal dunia. Investor di pasar modal internasional dapat mendiversifikasi portofolionya dengan membeli efek di pasar modal dan memantau pergerakan indeks asing untuk melakukan prediksi di masa depan (Venska et al., 2014).Pergerakan indeks juga dipengaruhi oleh beberapa faktor, seperti faktor dari luar negeri (eksternal) dan faktor yang berasal dari dalam negeri (internal) (Laksmiwati, 2006). Faktor eksternal berasal dari berbagai indeks di seluruh dunia terutama bursa yang berasal dari Negara-negara maju 
Febrian Wahyu Wibowo: Pengaruh Tingkat Suku Bunga

merupakan indeks yang sangat mempengaruhi indeks di Negara lain. Adapun beberapan indeks yang berpengaruh pada indeks Negara lain seperi Dow Jones Islamic Indeks dari Amerika, Nikkei 225 dari Jepang, dan Straits Times Index dari Singapura (Muzamil, 2011). Dengan demikian dapat diketahui bahwa seluruh indeks pasar modal global saling terintergrasi satu dengan yang lainnya, hal tersebut mengindikasikan bahwa pergerakan harga pada salah satu indeks pasar modal akan mempengaruhi indeks pasar modal lainnya. Walaupun investor shariah compliant menjadikan batasan-batasan syariah sebagai referensi utama dalam berinvestasi, namun variabel-variabel lain yang berkaitan dengan pergerakan indeks saham syariah harus tetap diperhatikan untuk proses pengambilan keputusan investasi.

\section{KAJIAN PUSTAKA}

Metwally (1984) mengatakan bahwa dalam perekonomian islam tidak diperbolehkan melakukan pinjaman berbungan dan diperbolehkan dengan berbasis berbagai risiko dan keuntungan, eksistensi bursa saham yang berfungsi dengan baik sangatlah penting. Bursa saham dapat memobilisasi tabungan untuk tujuan investasi sekaligus memberikan likuiditas kepada pemegang saham atau investor.Untuk membuat keputusan dalam berinvestasi yang menguntungkan, seorang investor harus mampu memperhatikan beberapa indikator makroekonomi yang dapat membantu dalam memahami dan memprediksi kondisi makroekonomi (Tandelin, 2010). Faktor makroekonomi merupakan faktor yang berada diluar perusahaan namun berpengaruh kepada kenaikan atau penurunan kinerja perusahaan baik secara langsung maupun tidak langsung.

Makroekonomi berfokus pada perilaku dan kebijakan ekonomi yang mempengaruhi konsumsi dan investasi, neraca perdagangan dan pembayaran suatu Negara, faktor-faktor yang mempengaruhi perubahan harga dan upah, kebijakan fiscal dan moneter, jumlah uang beredar, tingkat suku bunga dan jumlah utang suatu Negara. Secara ringkas makroekonomi berhubungan dengan masalah-masalah ekonomi intinya adalah pada interaksi antara perputaran barang, tenaga kerja, dan asset asset ekonomi serta interaksi diantara Negara- Negara yang melakukan kegiatan perdagangan (Dornbusch, 2011). 
Febrian Wahyu Wibowo: Pengaruh Tingkat Suku Bunga

Perubahan variabel makroekonomi dapat mempengaruhi kinerja perusahaan dalam jangka panjang. Perubahan variabel makroekonomi sangat mempengaruhi harga saham, karena para investor akan menghitung dampak positif maupun negatif dari perubahan tersebut terhadap kinerja perusahaan beberapa tahun kedepan untuk kemudian mengambil keputusan membeli atau menjual saham yang bersangkutan. Karena itu, harga saham lebih cepat menyesuaikan diri terhadap perubahan variabel-variabel mekroekonomi (Samsul, 2006).

Beberapa faktor makroekonomi yang secara langsung dapat mempengaruhi kinerja saham maupun kinerja perusahaan antara lain adalah tingkat suku bunga domestik, kurs valuta asing, kondisi perekonomian internasional, siklus ekonomi suatu Negara, tingkat inflasi, peraturan perpajakan dan jumlah uang beredar (Samsul, 2006).

\section{HIPOTESIS}

Marom mengungkapkan bahwa tingkat bunga berpengaruh negatif dan signifikan terhadap Jakarta Islamic Index (Marom, 2010). Tingkat suku bunga akan menyebabkan harga saham turun, hal ini terjadi karena pada saat tingkat suku bunga yang meningkat, investor akan cenderung menjual sahamnya dan mengalihkan dananya dalam bentuk deposito atau tabungan agar memperoleh keuntungan yang tinggi dengan tingkat risiko yang lebih aman, kecenderungan tersebur akan mendorong harga saham turun, dan selanjutnya secara otomatis akan menyebabkan juga penurunan pada indeks saham. Dengan demikian hipotesis penelitian dirumuskan sebagai berikut:

\section{$H_{1}$ : Tingkat Suku Bunga berpengaruh negatif terhadap Indeks Saham Syariah Indonesia.}

Pergerakan indeks saham juga dipengaruhi oleh indeks pasar modal global di seluruh dunia, teori mengenai integrasi pasar modal yang menggunakan model The Generalized Auto Regresissive Conditional Heteroscedasticty Model "GARCH", Granger Causality and Vector Auto Regressive "VAR". Integrasi pasar modal terjadi apabila mereka memiliki hubungan equilibrium yang berkelanjutan (Amir, 2006). Dengan kata lain adanya pergerakan bersama antara pasar-pasar modal, mengindikasikan adanya integrasi bersama antar pasar modal, yang 
Febrian Wahyu Wibowo: Pengaruh Tingkat Suku Bunga

mengakibatkan bahwa salah satu dari pasar modal yang terintegrasi tersebut dapat digunakan untuk memprediksi return dari pasar modal yang lain, karena koreksi nilai error yang valid dari tiap pasar modal akan ada (Vogel, 1997). Penelitian yang dilakukan oleh Gultom (2013) tentang pengaruh indeks Nikkei 225, Indeks Dow Jones, Straits Times Indeks terhadap IHSG selama periode 2000-2009 dengan metode regresi berganda, menemukan bahwa Indeks Nikkei, Dow Jones, dan Straits Times berpengaruh positif terhadap IHSG. Dengan demikian hipotesis penelitian dirumuskan sebagai berikut:

\section{H2: Indeks DJIM berpengaruh positif terhadap Indeks Saham Syariah Indonesia.}

Tidak hanya indeks Dow Jones yang mempengaruhi pergerakan antar pasar modal global di seluruh dunia, Nikkei 225 juga merupakan salah satu indeks pasar modal global yang mempengaruhi pergerakan pasar modal lainnya seperti yang di jelaskan pada penelitian Venska (2014) tentang pengaruh indeks bursa global (Dow Jones Industrial Average, Nikkei 225 dan Straits Times) terhadap IHSG untuk periode tahun 2010-2012 dengan menggunakan metode analisis regresi berganda, menemukan bahwa indeks Dow Jones, Nikkei 225 dan Straits Times secara simultan memiliki pengaruh signifikan terhadap IHSG namun secara parsial hanya Indeks Dow Jones, Nikkei 225, dan Straist Times berpengaruh signifikan terhadap IHSG pada periode 2010-2012. Dengan demikian hipotesis penelitian dirumuskan sebagai berikut:

\section{H3: Indeks Nikkei 225 berpengaruh positif terhadap Indeks Saham Syariah Indonesia.}

Indeks Straits Time dari singapura juga termasuk salah satu indeks yang berpengaruh terhadap pergerakan indeks pasar modal global dunia, sebagaimana penelitian yang dilakukan oleh Kowanda (2014) menguji pengaruh Bursa Saham Global, ASEAN dan Harga Komoditas Terhadap IHSG, dan Nilai Tukar EUR/USD. Penelitian tersebut menggunakan metode regresi linear berganda dengan periode penelitian dari tahun 2008 sampai dengan tahun 2013. Hasil penelitian menemukan bahwa indeks Dow Jones, FTSE 100, Indeks Nikkei, Sanghai Stock Exchange, Indeks Straits Times, harga Minyak, dan Harga Emas 
Febrian Wahyu Wibowo: Pengaruh Tingkat Suku Bunga

berpengaruh signifikan terhadap IHSG dan Nilai Tukar EUR/USD. Dengan demikian hipotesis penelitian dirumuskan sebagai berikut:

\section{H4: Indeks Straits Times berpengaruh positif terhadap Indeks Saham Syariah Indonesia.}

Metode

Objek dalam penelitian ini adalah Indeks Saham Syariah Indonesia (ISSI) yang memiliki konstituen seluruh saham syariah yang terdaftar di Bursa Efek Indonesia berdasarkan Daftar Efek Syariah (DES) yang dikeluarkan oleh Otoritas Jasa Keuangan bekerja sama dengan DSN-MUI. Penelitian ini memiliki satu variabel terikat (dependen) dalam hal ini adalah indeks harga saham syariah Indonesia. Angka indeks yang diambil adalah angka indeks harga penutupan bulanan selama periode Mei 2011 sampai dengan September 2015. Kemudian lima variabel bebas (independen) yang terdiri dari atas tingkat suku bunga yang mengacu pada tingkat suku bunga BI Rate, nilai tukar USD terhadap Rupiah yang diambil rata-rata perbulan, dan Indeks Dow Jones Islamic Market, Indeks Nikkei 225 serta Indeks Straits Time yang diambil adalah angka indeks harga penutupan bulanan selama periode Juni 2012 sampai dengan Maret 2017.

Populasi yang digunakan adalah pergerakan saham syariah yang tercatat di Bursa Efek Indonesia selama bulan Juni 2012 sampai dengan Maret 2017 penentuan periode ini dilakukan karena pertimbangan data bulanan yang diperoleh mencukupi 58 periode. Dengan demikian, jumlah tersebut sudah memnuhi ukuran sampel kecil untuk data distribusi normal.Data yang digunakan merupakan data sekunder yang berasal dari harga penutupan saham bulanan berdasarkan data yang diambil dari Bloomberg.Dipilihnya Indeks Saham Syariah Indonesia sebagai indeks syariah yang terdiri dari saham-saham yang terdaftar dari Daftar Efek Syariah.

Penelitian ini menggunakan teknik analisis data kuantitatif, dengan memperkirakan secara kuantitatif pengaruh dari beberapa variabel independen secara bersama-sama maupun secara individual terhadap variabel dependen. Hubungan fungsional antara satu variabel dependen dengan variabel independen dilakukan dengan regresi linear berganda dengan model persamaan sebagai berikut: 
Febrian Wahyu Wibowo: Pengaruh Tingkat Suku Bunga

ISSI $=\alpha+\beta_{1}$ SB $_{t}+\beta_{2}$ DJIM $_{t}+\beta_{3} \mathrm{NIK}_{t}+\beta_{4}$ STI $_{t}+\varepsilon$

Dimana:

ISSI

: Indeks Saham Syariah Indonesia

$\beta$

: Koefisien Regresi

SB

: Tingkat Suku Bunga

DJIM

: Dow JonesIslamic MarketWorld Index

NIK

: Indeks Nikkei 225

STI

: Indeks Straits Time

$\varepsilon$

: Standar error

HASIL DAN PEMBAHASAN

Tabel 1

Hasil Uji Statistik Deskriptif

\begin{tabular}{|l|l|l|l|l|l|}
\hline & N & Minimum & Maksimum & Mean & $\begin{array}{l}\text { Std. } \\
\text { Deviation }\end{array}$ \\
\hline $\begin{array}{l}\text { Suku } \\
\text { Bunga }\end{array}$ & 58 & 4,75 & 7,75 & 6,5662 & 1,05444 \\
\hline DJIM & 58 & 2085,98 & 3029,98 & 2539,2241 & 281,49483 \\
\hline Nikkei 225 & 58 & 8635,44 & 20551,46 & 15646,8431 & 3298,82085 \\
\hline $\begin{array}{l}\text { Striats } \\
\text { Times }\end{array}$ & 58 & 2629,11 & 3487,15 & 3106,4728 & 216,17970 \\
\hline ISSI & 58 & 13,16 & 174,32 & 94,0940 & 71,66292 \\
\hline
\end{tabular}

Sumber: Hasil Pengolahan SPSS

Pada Tabel 1 diperoleh hasil bahwa nilai rata-rata BI Rate selama periode penelitian adalah 6,5 dengan nilai tertinggi 7,75 dan nilai terendah adalah sebesar 4,75. Nilai standar deviasi tingkat suku bunga BI Rate adalah sebesar 1,05444. Hal ini menunjukkan nilai BI Rate yang berfluktuasi normal.

Pada Tabel 1 diperoleh hasil bahwa nilai rata-rata Dow Jones Islamic Market selama periode penelitian adalah 2539,2241 dengan nilai tertinggi 3029,98 dan nilai terendah adalah sebesar 2085,98. Nilai standar deviasi Dow JonesIslamic Market adalah sebesar 281,29283.

Pada Tabel 1 diperoleh hasil bahwa nilai rata-rata Nikkei 225 selama periode penelitian adalah 15646,8431 dengan nilai tertinggi 20551,46 dan nilai terendah adalah sebesar 8635,44 . Nilai standar deviasi tingkat suku bunga Nikkei 225 adalah sebesar 3298,82085.

Pada Tabel 1 diperoleh hasil bahwa nilai rata-rata Straits Times selama periode penelitian adalah 3106,4728 dengan nilai tertinggi 
Febrian Wahyu Wibowo: Pengaruh Tingkat Suku Bunga

3487.15 dan nilai terendah adalah sebesar 2629.11. Nilai standar deviasi tingkat suku bunga Straits Times adalah sebesar 216.17970.

Pada Tabel 1 diperoleh hasil bahwa nilai rata-rata Indek Saham Syariah Indonesia selama periode penelitian adalah 94,0940 dengan nilai tertinggi 174,32 dan nilai terendah adalah sebesar 13,16. Nilai standar deviasi tingkat suku bunga Indek Saham Syariah Indonesia adalah sebesar 71,66292.

\section{UJI F}

Uji $F$ bertujuan untuk menguji pengaruh variabel-variabel independen secara bersama sama terhadap variabel dependen. Dalam penelitian ini uji $\mathrm{F}$ digunakan untuk mengevaluasi pengaruh dari Tingkat Suku Bunga, Dow JonesIslamic Market, Nikkei 225, dan Indeks Straits Times terhadap Indeks Saham Syariah Indonesia (ISSI) secara simultan.

Tabel 2

Hasil Pengujian Simultan

\begin{tabular}{|l|l|l|c|c|}
\hline \multicolumn{2}{|c|}{ Model } & Sum of Squares & F & Sig. \\
\hline 1 & Regression & 8,873 & 27,747 & 0,000 \\
\hline & Residual & 8,839 & & \\
\hline & Total & 7,712 & & \\
\hline
\end{tabular}

Sumber: Pengolahan SPSS

Dari Tabel 2 didapat F-hitung sebesar 27.747 dengan probabilitas 0.000.karena nilai probabilitas jauh lebih kecil dari 0.05, maka model regresi dapat digunakan untuk memprediksi Indeks Saham Syariah Indonesia (ISSI) atau dapat dikatakan bahwa Tingkat Suku Bunga, Dow JonesIslamic Market, Nikkei 225, dan Indeks Straits Times secara bersama-sama berpengaruh terhadap Indeks Saham Syariah Indonesia (ISSI).

\section{UJI T}

Tujuan dari uji $\mathrm{t}$ adalah untuk melihat pengaruh antara variabel independen terhadap variabel dependen secara parsial atau terpisah.Uji t dilakukan untuk membuktikan penerimaan atau penolakan terhadap H0 dari hipotesis pada penelitian ini berdasarkan model persamaan berikut:

$$
\text { ISSI }=\alpha+\beta_{1} \mathrm{SB}_{t}+\beta_{2} \mathrm{DJIM}_{t}+\beta_{3} \mathrm{NIK}_{t}+\beta_{4} \mathrm{STI}_{t}+\varepsilon
$$


Febrian Wahyu Wibowo: Pengaruh Tingkat Suku Bunga

Tabel 3

Hasil Pengujian Parsial

\begin{tabular}{|l|l|l|l|l|}
\hline \multirow{3}{*}{ Model } & \multicolumn{2}{|c|}{ Usntandardized Coeficients } & & \multirow{2}{*}{} \\
\cline { 2 - 3 } & \multicolumn{1}{|c|}{$\mathrm{B}$} & \multicolumn{1}{|c|}{ Std. Error } & \multicolumn{1}{c|}{ T } & Sig. \\
\hline (Constant) & $-477,005$ & 99,881 & $-4,776$ & 0,000 \\
\hline Suku Bunga & 12,102 & 8,209 & 1,474 & 0,146 \\
\hline DJIM & 0,077 & 0,051 & 1,509 & 0,137 \\
\hline Nikkei 225 & $-0,010$ & 0,002 & $-4,578$ & 0,000 \\
\hline Straits Times & 0,145 & 0,049 & 2,957 & 0,005 \\
\hline
\end{tabular}

Sumber: Hasil Pengolahan SPSS

Persamaan regresi yang terbentuk adalah:

\section{ISSI $=-477.005+12.102$ SB + 0.077 DJIM -.010 Nikkei $225+0.145$ $\mathrm{ST}+\mathrm{e}$}

Berdasarkan hasil uji t pada Table 3 diatas diperoleh hasil sebagai berikut :

Dari Tabel 3 untuk variabel Suku Bunga diperoleh t-hitung $=1.474$ dan nilai signifikansi t-hitung adalah sebesar 0,146 . Hasil perhitungan pada tabel statistik (dengan nilai signifikansi 0,05 dan $\mathrm{df}=58-5-1=52$ ) diperoleh nilai t-tabel sebesar 1.675 (t-hitung lebih kecil dari t-tabel) dan nilai signifikansi lebih besar dari 0,05. Maka dari perhitungan tersebut dapat disimpulkan untuk menerima H0 dan menolak H1.

Berdasarkan pengujian ini dapat diperoleh kesimpulan bahwa dengan derajat keyakinan 95\% Tingkat Suku Bunga berpengaruh negatif terhadap Indeks Saham Syariah Indonesia.Tingkat suku bunga yang di tentukan oleh kebijakan Bank Indonesia, besar dan kecilnya suku bunga mempengaruhi investor dalam mengalokasikan dananya. Semakin besar suku bunga maka investor akan cenderung memilih untuk memindahkan dana investasinya dari pasar modal ke instrument keuangan yang lebih menjanjikan bunga yang lebih tinggi, apabla hal ini terjadi maka akan menurunkan harga-harga indeks.Penelitian yang dilakuka oleh Hoshmandy (2014) menyimpulkan bahwa tingkat suku bunga memberikan pengaruh terhadap harga saham.Hal ini sesuai dengen penelitian Luthfi Sirojul Marom yang mengungkapkan bahwa tingkat bunga berpengaruh negatif terhadap Jakarta Islamic Index (Marom, 2010). 
Febrian Wahyu Wibowo: Pengaruh Tingkat Suku Bunga

Dari Tabel 3 untuk variabel DJIM diperoleh t-hitung = 1.509 dan nilai signifikansi t-hitung adalah sebesar 0,137. Hasil perhitungan pada tabel statistik (dengan nilai signifikansi 0,05 dan df = 58-5-1 = 52) diperoleh nilai t-tabel sebesar 1.675 (t-hitung lebih kecil dari t-tabel) dan nilai signifikansi lebih besar dari 0,05. Maka dari perhitungan tersebut dapat disimpulkan untuk menerima H0 dan menolak $\mathrm{H} 2$.

Berdasarkan pengujian ini dapat diperoleh kesimpulan bahwa dengan derajat keyakinan 95\% Indeks DJIM berpengaruh positif terhadap Indeks Saham Syariah Indonesia.Sebagaimana yang telah diketahui bahwa DJIM merupakan salah satu indeks yang sangat mempengaruhi indeks saham dunia lainnya. DJIM merupakan kelompok indeks yang terdiri dari sub indeks regional, sub indeks Negara, sub indeks industri dan sub indeks berbasis kapitalis yang semua itu menginduk pada DJIM. Hal ini sesuai dengan penelitian Gultom (2013) yang meneliti pengaruh indeks Nikkei 225, Indeks Dow Jones, Straits Times Indeks terhadap IHSG selama periode 2000-2009 dengen metode regresi berganda. Hasil penelitian menemukan bahwa Indeks Nikkei, Dow Jones, dan Straits Times berpengaruh positif terhadap IHSG.

Dari Tabel 3 untuk variabel Nikei 225 diperoleh t-hitung $=4.578$ dan nilai signifikansi t-hitung adalah sebesar 0,000. Hasil perhitungan pada tabel statistik (dengan nilai signifikansi 0,05 dan $\mathrm{df}=58-5-1=52$ ) diperoleh nilai t-tabel sebesar 1.675 (t-hitung lebih besar dari t-tabel) dan nilai signifikansi lebih kecil dari 0,05. Maka dari perhitungan tersebut dapat disimpulkan untuk menolak H0 dan menerima H3.

Berdasarkan pengujian ini dapat diperoleh kesimpulan bahwa dengan derajat keyakinan 95\% Indeks Nikkei 225 berpengaruh nagatif terhadap Indeks Saham Syariah Indonesia.Nikkei merupakan salah satu indeks yang sangat berpengaruh, hal ini di sebabkan oleh Negara Jepang merupakan Negara yang sangat mempengaruhi perputaran ekonomi dunia (Surbakti, 2011). Menurut data World bank pertahun 2015, Jepang mempunyai PDB sebesar 4.123 triliun dillar AS yang membuat Jepang memiliki pengaruh dalam hal perekonomian dunia. Hal ini berbeda dengan penelitian Venska, et al., (2014) meneliti pengaruh indeks bursa global (Dow Jones Industrial Average, Nikkei 225 dan Straits Times) terhadap IHSG untuk periode tahun 2010-2012 dengan menggunakan metode analisis regresi berganda. Hasilnya adalah indeks Dow Jones, Nikkei 225 dan Straits Times secara simultan memiliki pengaruh 
Febrian Wahyu Wibowo: Pengaruh Tingkat Suku Bunga

signifikan terhadap IHSG namun secara parsial hanya Indeks Dow Jones, Nikkei 225, dan Straist Times berpengaruh signifikan terhadap IHSG pada periode 2010-2012. Perbedaan tersebut dikarenakan penelitian sebelumnya berbeda dalam hal jumlah sampel yang digunakan, variabel yang digunakan dan juga rentang waktu penelitian yang berbeda.

Dari Tabel 3 untuk variabel Straits Times diperoleh t-hitung $=2.957$ dan nilai signifikansi t-hitung adalah sebesar 0,005. Hasil perhitungan pada tabel statistik (dengan nilai signifikansi 0,05 dan $\mathrm{df}=58-5-1=52$ ) diperoleh nilai t-tabel sebesar 1.675 (t-hitung lebih besar dari t-tabel) dan nilai signifikansi lebih kecil dari 0,05. Maka dari perhitungan tersebut dapat disimpulkan untuk menolak H0 dan menerima $\mathrm{H} 4$.

Berdasarkan pengujian ini dapat diperoleh kesimpulan bahwa dengan derajat keyakinan 95\% Straits Times 225 berpengaruh nagatif terhadap Indeks Saham Syariah Indonesia. Hal ini berbeda dengan penelitian Kowanda, et al (2014) menguji pengaruh Bursa Saham Global, ASEAN dan Harga Komoditas Terhadap IHSG, dan Nilai Tukar EUR/USD. Penelitian tersebut menggunakan metode regresi linear berganda dengan periode penelitian dari tahun 2008 sampai dengan tahun 2013. Hasil penelitian menemukan bahwa: Indeks Dow Jones, FTSE 100, Indeks Nikkei, Sanghai Stock Exchange, Indeks Straits Times, harga Minyak, dan Harga Emas berpengaruh signifikan terhadap IHSG dan Nilai Tukar EUR/USD. Indeks Dow Jones, indeks Nikkei, SSEC, Indeks Staits Times, dan Harga Minyak berpengaruh signifikan terhadap IHSG (Indeks Nikkei berimplikasi negatif). Perbedaan tersebut dikarenakan penelitian sebelumnya berbeda dalam hal jumlah sampel yang digunakan, variabel yang digunakan dan juga rentang waktu penelitian yang berbeda.

\section{KESIMPULAN}

Berdasarkan pembahasan yang telah dikemukakan mengenai pengaruh variabel Tingkat Suku Bunga, Dow JonesIslamic Market, Indeks Nikkei 225, dan Indeks Straits Times terhadap variabel Indeks Saham Syariah Indonesia untuk periode Juni 2012 sampai dengan Maret 2017 dapat di ambil kesimpulan sebagai berikut:

1. Tingkat Suku Bunga berpengaruh negatif terhadap Indeks Saham Syariah Indonesia.

2. Dow Jones Islamic Market berpengaruh positif terhadap Indeks Saham Syariah Indonesia. 
Febrian Wahyu Wibowo: Pengaruh Tingkat Suku Bunga

3. Nikkei 225 berpengaruh negatif terhadap Indeks Saham Syariah Indonesia.

4. Straits Times berpengaruh negatif terhadap Indeks Saham Syariah Indonesia.

\section{SARAN}

Hasil Penelitian ini menunjukkan bahwa Indeks Saham Syariah Indonesia pada periode Juni 2012 sampai dengan Maret 2017 dipengaruhi oleh Tingkat Suku Bunga, Dow Jones Islamic Market, Nikkei 225, dan Straits Times. Berdasarkan analisis dan pembahasan hasil penelitian, disampaikan beberapa saran yang dapat menjadi masukan sebagai berikut:

Terkait penelitian di masa mendatang

1. Penelitian selanjutnya dapat dilakukan dengan meneliti periode penelitian yang lebih panjang agar dapat memberikan hasil dan pembahasan yang lebih luas.

2. Penelitian selanjutnya dapat menambahkan variabel-variabel lain terkait dengan Indeks Saham Syariah Indonesia, agar dapat memperkaya penelitian dan mendapat hasil yang lebih luas di banding penelitian sebelumnya.

3. Penelitian selanjutnya dapat melakukan penelitian lebih focus pada salah satu sektor yang terapat pada pasar modal global

\section{DAFTAR PUSTAKA}

Abu al-Walid Muhammad ibn Ahmad ibn Muhammad ibn Ahmad ibn Rusyd al-Qurtubi, Bidayah al-Mujtahid wa an-Nihayah alMuqtasid (Beirut: Dar al-Ma'rifah, 1981),

Ab. Mumin Ab. Ghani \& Fadillah Mansor. 2006. Dinamisme Kewangan Islam di Malaysia (Kuala Lumpur: University Malaya)

Adrian, Nicko. 2011. "Analisis Faktor-faktor yang Mempengaruhi Peringkat Obligasi pada Perusahaan Manufaktur yang Terdaftar di Bursa Efek Indonesia", Skripsi Manajemen, Fakultas Ekonomi Universitas Diponegoro, Semarang.

Amir, Muhammad Faisal. 2006. Mengolah dan Membuat Interpretasi Hasil Olahan SPSS Untuk Penelitian Iimiah. Jakarta: Penerbit Edsa Mahkota,

Ascarya. 2007. Akad \& Produk Bank Syariah. Jakarta: Raja Grafindo

EL DINAR Volume 7, No.1, Tahun 2019 | 43 
Febrian Wahyu Wibowo: Pengaruh Tingkat Suku Bunga

Bodie, Zvi., Kane, Alex., Markus, Alan J., dan Jain, Ravi. 2014. Investments, Asia Global Edition. New York: McGrawHill International Edition.

Chen, N. F., Roll, R., \& Ross, S. A. 1986. Economic forces and the stock market.Journal of Business, 59, 383e403.

Dornbusch, R., Fischer, S., dan Richard Starz. 2011. Macroeconomics. New York: McGrawHill International Edition. Eleventh Edition.

Endri. 2008. Integrasi Pasar Saham ASEAN-5: Analisis Sebelum dan Sepanjang Krisis Keuangan Global 2007-2008. Jurnal Keuangan dan Perbankan, Vol. 14, No. 2 hal: 205-219.

El-Diwani, Tarek. 2003. The Problem With Interest Jakarta: Akbar Media Eka Sarana, h. 38-39.

Firduasi, AN, Fahmi \& Saptono IT. 2016. Pengaruh Indeks Harga Saham Regional ASEAN dan Variabel Makroekonmi terhadap Indeks Harga Saham Syariah Indonesia (ISS). Jurnal Al-Muzara'ah Vol.4, No 2., ISSN p. 2337-6333; e:2355-4363.

Ghozali, Imam. 2005. Aplikasi Analisis Multivariate dengan Program SPSS.

Semarang: Badan Penerbit Universitas Diponegoro.

Ghufron, Sofiniyah. 2005. Konsep dan Implementasi Bank Syari'ah, Jakarta: Renaisan.

Gultom, Mangandar Tua. 2013. Analisis Pengaruh Indeks Nikkei 225, Indeks Dow Jones, Straits Times Index Terhadap IHSG. [Tesis], Program Studi Magister Manajemen, Universitas Gadjah Mada.

Halim, Abdul. 2005. Analisis investasi. Edisi ke-2.Jakarta : Salemba 4

Hartono, Jogiyanto. 2013. Teori Portofolio dan Analisis Investasi. Yogyakarta: BPFE UGM. Edisi ke 8.

Ho, Catherine SF. 2011. Domestic Macroeconomic Fundamentals and World Stock Market Effects on ASEAN Emerging Markets. International Journal of Economics and Management 5(1), h. 1 18.

Hoshmandy, Hamis. 2014. A Comparison between Different Factors Affecting the Stock Mark et Price Index Among Selected Members of the Organization of The Islamic Conference (OIC). Journal of Applied Environmental and Biological Science, 4(10S)13-17.

Jogiyanto. 2007. Teori Portofolio dan Analisis Investasi, Edisi Kelima. Yogyakarta: BPFE. 
Febrian Wahyu Wibowo: Pengaruh Tingkat Suku Bunga

Kandir, Serkan Yilmaz. 2008. Macroeconomic Variabels, Firm Characteristics and Stock Returns: Evidence from Turkey. International Research Journal of Finance and Economics Issue 16, h. 20-45.

Kasmir. 2004. Bank \& Lembaga Keuangan Lainnya, Jakarta: PT Raja Grafindo Persada.

Kewal, Suramaya. 2012. Pengaruh Inflasi, Suku Bunga, Kurs, dan Pertumbuhan PDB Terhadap Indeks Harga Saham Gabungan. Jurnal Economia Volume 8, No. 1, April2012. Universitas Negeri Yogyakarta. Hal 101-120

Kowanda, Binastuti, Pasaribu dan Ellim. 2014. Pengaruh Bursa Saham Global , ASEAN dan harga komoditas terhadap IHSG, dan Nilai Tukar EUR/USD, Jurnal Akuntansi \& Manajemen Vol. 23, No. 2 Agustus.

Lind, Douglas., Marchal, William., and Wathen, Samuel. 2013. Statistical Techniques in Business and Economics, Fifteenth edition.McGrawHill International Edition.

Mobius. J. M. 1998. Mobius On Emerging Market : Prospek Investasi di Pasar-Pasar Baru. Jakarta : Elex Media Komputindo

Mansur, Moh. 2005. Pengaruh Indeks Bursa Global terhadap Indeks Harga Saham Gabungan (IHSG) pada Bursa Efek Jakarta (BEJ) Periode Tahun 2000-2002. Sosiohumaniora, Vol. 7, No. 3. 203 219.

Marom, Lutfi Sirojul. 2010. Pengaruh Variabel Makroekonomi Terhadap Jakarta Islamic Index di Bursa Efek Indonesia.

Metwally, Mokhtar M. 1984. The Role of the Stock Exchange in An Islamic Economy. Journal for Research in Islamic Economics, Vol 2 No 1. 58-68.

Moran, David E. 2011. The Role of the Dow Jones Islamic Market Index in Islamic Finance. Proceedings of the Third Harvard University Forum on Islamic Finance: Local Challenges, Global Opportunities Cambridge, Massachusetts. Center for Middle Eastern Studies, Harvard University. pp. 257-258.

Muzammil, A. 2011. Analisis pengaruh indeks Saham Asia Tenggara terhadap Indeks Harga Saham Gabungan (IHSG) di Bursa Efek Indonesia.Skripsi Universitas Pembangunan Nasional "Veteran", Jakarta, h 35-50 
Febrian Wahyu Wibowo: Pengaruh Tingkat Suku Bunga

Nazwar, Chairul. 2008. Analisis Pengaruh Variabel Makroekonomi terhadap Return Saham Syariah di Indonesia.Wahana Hijau Jurnal Perencanaan \& Pengembangan Wilayah Volume 4, Nomor 1 , Agustus.

Nopirin. 1992. Ekonomi Moneter Buku 1, Yogyakarta: BPEE-Yogyakarta, Edisi ke-4

Pasaribu, Rowland dan Firdaus, Mikail. 2013. Analisis pengaruh Variabel Makroekonomi terhadap Indeks Saham Syariah Indonesia.Jurnal Ekonomi \& Bisnis Volume 7, No.2Juli 2013.STIE YKPN Yogyakarta.21-37

Pieper P, \& Vogel R. 1997. The Stock Market Integration In Latin America, CAER II Discussion Paper No. 21, Harvard Institute for International Development.

Pudjiastuti. 2004. Dasar-Dasar Manajemen Keuangan.Edisi. Keempat, Yogyakarta, UPP AMP YKPN.

Rasyidi, M. 1976. Hukum Islam dan Pelaksanaannya dalam Sejarah. Jakarta: Bulan Bintang.

Rigobon, R., \& Sack, B. 2004. The impact of monetary policy on asset prices. Journal of Monetary Economics, 51, 1553-1575.

Saeed, Abdullah. 1996. Islamic Banking And Interest: A Studi of Prohibition Riba and its Contemporary Interpretation. (LeidenNew York: E.J. Brill

Samsul, Mohamad. 2006. Pasar Modal \& Manajemen Portofolio. Jakarta: Erlangga.

Samuelson dan Nordhaus. 2010. Microeconomics, Nineteenth edition. McGrawHill International Edition.

Shihab, M. Quraish. 2008. Tafsir al-Misbah. Jakarta: Lentera Hati. Vol. II.

Sholahuddin. 2006. Lembaga Ekonomi dan Keuangan Islam, Surakarta: Muhammadiyah University Press.

Singarimbun, Masri dan Sofian Effendi. 2008. Metode Penelitian Survei, Jakarta: LP3ES.

Sujarweni, V Wiratna. 2014. SPSS untuk Penelitian, Pustaka Baru Press, Yogyakarta.

Sugiyono. 2007. Statistika Untuk Penelitian. Bandung: Alfabeta

Sugiyono. 2012. Metode Penelitian Kuantitatif Kualitatif dan R\&D. Bandung: Alfabeta. 
Febrian Wahyu Wibowo: Pengaruh Tingkat Suku Bunga

Sunariyah. 2006. Pengantar Pengetahuan Pasar Modal, Edisi Kelima, UPP STIM YKPN, Yogyakarta.

Sunariyah. 2004. Pengantar Pengetahuan Pasar Modal, UPP AMP YKPN, Yogyakarta.

Tandelilin, Eduardus. 2010. Portofolio dan Investasi: Teori dan Aplikasi. Kanisius, Yogyakarta.

Venska, Suhadak dan Handayani. 2014. The Effect of Global Stock Indexs (Dow Jones Industrial Average, Nikkei 225, Hang Seng, and Straits Times) On Jakarta Composite Index at Indonesian Stock Exchange. (Period of 2010 - 2012). Jurnal Administrasi Bisnis $(J A B) \mid$ Vol. 9 No. 2 h. 51- 61. April. Brawijaya University Malang.

Wandabio, L. S. 2006. Analisis hubungan indeks Harga Saham Gabungan (IHSG) Jakarta (JSX), London (FTSE), Tokyo Nikkei) dan Singapura (SSI).Simposium Nasional Akuntansi 9, Padang.H. 255278, 2006

Witjaksono, Ardian Agung. 2010. Analisis Pengaruh Tingkat Suku Bunga SBI, Harga Minyak Dunia, Harga Emas Dunia, Kurs Rupiah, Indeks Nikkei 225, dan Indeks Dow Jones terhadap IHSG. (Studi kasus pada IHSG di BEI selama periode 2000-2009)[Tesis], Program Studi Magister Manajemen, Universitas Diponegoro.h 78-90

Yati Kurniati, Samsu Arifin dan Winanto. 2007. Integrasi Keuangan dan Moneter Di Asia Timur : Peluang dan Tantangan Bagi Indonesia. 